\title{
Relationship of platelet-lymphocyte ratio with severity of obstructive sleep apnea syndrome.
}

\author{
Zeeshan Anjum ${ }^{1}$, Sana Maqsood ${ }^{2}$, Sehrish Saeed ${ }^{3}$ \\ 4. House Officer Nishtar Hospital, Multan \\ 5. Medical officer Jinnah Hospital, Lahore \\ 6. Woman Medical Officer BHU Chak 18 \\ Corresponding Author: zeeshananjum654@gmail.com
}

Abstract

Objective: Objective of study was to assess the inflammation in obstructive sleep apnea syndrome patients by using platelet lymphocyte ratio and relationship between platelet lymphocyte ratio and severity of obstructive sleep apnea.

Study Design: Cross sectional study

Place and Duration: Pulmonology department of Nishtar Hospital Multan and Jinnah Hospital, Lahore from June 2018 to March 2019.

Methods: This cross sectional study was conducted in Pulmonology department of Nishtar Hospital Multan from June 2016 to March 2017.Total 280 patients were selected by non-probability consecutive sampling. All patients underwent whole night polysomnography. Patients were divided into control group (AHI $<5)$, mild OSAS group (AHI 5-15), moderate OSAS group (AHI 15-30) and sever OSAS group (AHI >30) according to their AHI score. Numerical variables like age, body mass index, white cell count, platelets, hemoglobin (Hb) and platelet lymphocyte ratio were statistically analyzed by mean and standard deviation and t-test applied to assess their significance. Qualitative variables like gender and smoking status were statistically analyzed by frequency and percentage. Chi square test was applied to check the significance. P value $<0.05$ was regarded as significant.

Results: Platelet lymphocyte ratio was significantly raised in patients with obstructive sleep apnea syndrome. There was significant correlation between platelet lymphocyte ratio and AHI $(p<0.05)$. So study showed that there was significant association between obstructive sleep apnea syndrome severity (represented by AHI) and systemic inflammation (represented by PLR). Significant differences were found between age $(p=0.000), E S R$ $(p=0.000)$, CRP $(p=0.003)$, Cholesterol $(p=0.000)$, Platelets $(p=0.048), H b(p=0.000)$, PLR $(p=0.000)$ and white blood cells $(p=0.000)$, in groups. Association was found between gender $(p=0.000)$ and smoking status $(p$ $=0.030)$ in groups. So, gender and smoking were the effect modifiers.

Conclusion: the observations of our study suggest that Platelet lymphocyte ratio was significantly raised in patients with obstructive sleep apnea syndrome. There was significant correlation between platelet lymphocyte ratio and AHI $(\mathrm{p}<0.05)$. So study showed that there was significant association between obstructive sleep apnea syndrome severity (represented by AHI) and systemic inflammation (represented by PLR).

Key words: Obstructive sleep apnea syndrome, Platelet lymphocyte ratio, polysomnography

DOI: $10.7176 / \mathrm{JMPB} / 54-08$

Publication date: April $30^{\text {th }} 2019$

Introduction:

Obstructive sleep apnea syndrome (OSAS) is very common sleep disorder $\{1\}$. Snoring is most common symptom of obstructive sleep apnea syndrome. It affects $7 \%$ of women and $20 \%$ of men in whole population $\{1\}$. It is one of the bigger health problem of adults. Upper airway collapse during sleep results in recurring apnea, disturbed sleep, excessive daytime sleepiness and intermittent hypoxia $\{2\}$. Most occurring nocturnal symptoms of obstructive sleep apnea syndrome are snoring and observed apneas. Disruption of normal sleep pattern and ventilation results in many complications through various pathophysiology. Obstructive sleep apnea syndrome patients suffer impaired quality of life and decrease performance status $\{1\}$. Several factors have been considered for development of obstructive sleep apnea syndrome. Obesity is one of major risk factor for developing obstructive sleep apnea syndrome $\{3\}$. It is reported that $70 \%$ patients of obstructive sleep apnea syndrome are obese $\{3\}$. Other risk factors are alcohol consumption, smoking, chronic pain and chronic opioid 
therapy $\{4\}$. This disorder develops due to reduction of the expansion forces of the pharyngeal dilator muscles, as it occurs in genioglossal muscle dysfunction and discoordination between the respiratory effort and inspiratory activity of the muscle. It is also reported that obstructive sleep apnea syndrome is associated with vitamin $\mathrm{D}$ deficiency $\{5\}$. Obstructive sleep apnea syndrome is contributing factor for many diseases. It is associated with cardiovascular diseases, neurological diseases and metabolic diseases $\{6\}$. So physicians should properly investigate and address this issue.

Many studies have shown that systemic inflammation, endothelial damage, oxidative stress, and increased coagulation factors in patients of obstructive sleep apnea syndrome are caused by many factors $\{7\}$. White blood cells and its subtypes are recognized inflammatory markers $\{8\}$. One of this is neutrophil-lymphocyte ratio (NLR). The rationale of this is because in inflammation there is decrease in lymphocytes count and increase in neutrophils count, so the ratio of these two can be used as marker of inflammation. Recent studies have shown platelet-lymphocyte ratio another inflammatory marker, that can predict adverse outcome in cardio vascular diseases $\{9\}$. Because platelet count is indicator of severity of inflammation. Pro-inflammatory cytokines stimulate the megakaryocytes that result in thrombocytosis $\{10\}$.

Like NLR, platelet lymphocyte ratio (PLR) is also associated with mortality of acute myocardial infarction $\{11\}$. But data is lacking about the association of inflammation in obstructive sleep apnea syndrome patients and platelet lymphocyte ratio. We want to investigate the issue in our region. So that it can help to establish the relationship between platelet lymphocyte ratio and severity of obstructive sleep apnea syndrome. It will also provide base for further research on this topic in coming days. Study done by Yeo-Jeong Song Et al. was taken as reference study $\{20\}$.

Methods and materials:

This cross sectional study was conducted in Pulmonology department of Nishtar Hospital Multan and Jinnah Hospital, Lahore from June 2018 to March 2019.after approval of the study was taken from institutional ethical committee. Written permission was taken from all patients enrolled in study. Total 280 patients were selected by non-probability consecutive sampling. Patients with following disorders were excluded: 1) patients with history of any systemic disease like liver disease 2) history of secondary hypertension 3) complaint of respiratory infection and failure 4) central nervous system disorders 5) any history of malignancy 6) having critical illness with poor functional status 7)history of heart failure and acute coronary syndrome or having myocardial infarction or any revascularization procedure. Sample size of the study calculated by a reference study done by Yeo-Jeong Song Et al. For which confidence interval was taken as $95 \%$, power of study 80, odd ratio of platelet lymphocyte ratio was 3.37 (www.openepi.com).

All patients participated in study were enrolled from outpatient department. Patients who presented with history of fatigue, day time sleepiness, snoring and disturbed sleep were selected. Patients who had high malampati score and short neck and also having history of disturbed sleep and snoring were also selected. A detailed physical examination was conducted in each patient to investigate the features of obstructive sleep apnea syndrome, its complications and also any clues of other systemic disease. All patients with normal renal status and age between 18 to 80 were include. During first visit demographic variables like age, gender, weight, height, income, medication history and other diseases were recorded. All patients underwent polysomnography.

The system of polysomnography contains four channels of electroencephalogram and two channels of electrooculography, submental electromyography(EMG), pulse oximeter for recording oxygen saturation, thoracic and abdominal movements, electrocardiogram, tracheal sound and oronasal air flow. A complete cessation in airflow for more than 10s was taken as apnea. Air flow reduction $\geq 30 \%$ for greater than 10 s with 4 $\%$ decrease in oxygen saturation of patient was defined as hypopnea. $\{12\}$. Severity of obstructive sleep apnea was calculated by apnea hypopnea index. Apnea hypopnea index is number of events of apnea and hypopnea per hour during sleep. All patients were divided into four groups according to their apnea hypopnea index scores: 1) the control group with AHI <5, 2) mild OSAS group with AHI 5-15, 3) moderate OSAS group with AHI 16-30, and 4) severe OSAS group with AHI score $>30$.

Complete blood count was analyzed along with serum glucose, cholesterol, erythrocyte sediment rate and c reactive protein. Platelet lymphocyte ratio was calculated by dividing lymphocytes from platelets.

Data was analyzed by SPSS volume 23. Numerical variables like age, body mass index, white cell count, platelets, hemoglobin $(\mathrm{Hb})$ and platelet lymphocyte ratio were statistically analyzed by mean and standard deviation and t-test applied to assess their significance. Qualitative variables like gender and smoking status 
were statistically analyzed by frequency and percentage. Chi square test was applied to check the significance. $\mathrm{P}$ value $<0.05$ was regarded as significant.

Results:

Overall, $100 \%(n=280)$ patients were enrolled in this study; divided according to OSAS status i.e. control group $(n=63)$, mild OSAS group $(n=60)$, moderate group $(n=67)$ and severe OSAS group $(n=90)$. The mean age and BMI of the control group patients was $45.22 \pm 2.57$ years and $23.90 \pm 2.66 \mathrm{~kg} / \mathrm{m}^{2}$ respectively. There were $57.1 \%(n=36)$ males and $42.9 \%(n=27)$ females. Smoking status showed that there were $87.3 \%(n=55)$ nonsmokers and 12.7\% (n=8) were smokers. The mean age and BMI of the Mild OSAS group patients was $49.85 \pm 2.11$ years and $24.03 \pm 2.74 \mathrm{~kg} / \mathrm{m}^{2}$ respectively. There were $76.7 \%(\mathrm{n}=46)$ males and $23.3 \%(\mathrm{n}=14)$ females. Smoking status showed that there were $90 \%(n=54)$ non-smokers and $10 \%(n=6)$ were smokers. The mean age and BMI of the moderate OSAS group patients was $50.37 \pm 2.28$ years and $27.00 \pm 3.03 \mathrm{~kg} / \mathrm{m}^{2}$ respectively. There were $89.6 \%(n=60)$ males and $10.4 \%(n=7)$ females. Smoking status showed that there were $74.6 \%(\mathrm{n}=50)$ non-smokers and $25.4 \%(\mathrm{n}=17)$ were smokers. The mean age and BMI of the severe OSAS group patients was $52.34 \pm 2.60$ years and $26.54 \pm 2.66 \mathrm{~kg} / \mathrm{m}^{2}$ respectively. There were $82.2 \%(\mathrm{n}=74)$ males and $17.8 \%$ $(\mathrm{n}=16)$ females. Smoking status showed that there were $74.4 \%(\mathrm{n}=67)$ non-smokers and $25.6 \%(\mathrm{n}=23)$ were smokers. (Table. 1).

The mean ESR, CRP, cholesterol, platelets, lymphocytes, Hb, PLR and WBC of the control patients was $8.01 \pm 2.27 \mathrm{~mm} / \mathrm{hr}, 0.63 \pm 0.35 \mathrm{mg} / \mathrm{L}, 170.21 \pm 11.88 \mathrm{mg} / \mathrm{dl}, 221.35 \pm 12.11 \times 10^{9} / \mathrm{L}, 36.25 \pm 5.00 \%, 12.95 \pm 1.30$ $\mathrm{g} / \mathrm{dl}, 98.80 \pm 7.69$ and $6760.23 \pm 14.10 \times 10^{6} / \mathrm{L}$ respectively. The mean ESR, CRP, cholesterol, platelets, lymphocytes, Hb, PLR and WBC of the mild OSAS patients was $18.25 \pm 2.29 \mathrm{~mm} / \mathrm{hr}, 1.31 \pm 0.85 \mathrm{mg} / \mathrm{L}$, $185.72 \pm 5.58 \mathrm{mg} / \mathrm{dl}, 225.23 \pm 5.88 \times 10^{9} / \mathrm{L}, 35.20 \pm 2.66 \%, 15.26 \pm 2.14 \mathrm{~g} / \mathrm{dl}, 114.90 \pm 2.13$ and $7287.03 \pm 24.08$ $\times 10^{6} / \mathrm{L}$ respectively. The mean ESR, CRP, cholesterol, platelets, lymphocytes, Hb, PLR and WBC of the moderate OSAS patients was $17.71 \pm 9.27 \mathrm{~mm} / \mathrm{hr}, 0.78 \pm 0.33 \mathrm{mg} / \mathrm{L}, 190.42 \pm 11.21 \mathrm{mg} / \mathrm{dl}, 230.96 \pm 4.69 \times 10^{9} / \mathrm{L}$, $31.88 \pm 4.37 \%, 13.01 \pm 2.08 \mathrm{~g} / \mathrm{dl}, 121.63 \pm 5.53$ and $7314.83 \pm 23.36 \times 10^{6} / \mathrm{L}$ respectively. The mean ESR, CRP, cholesterol, platelets, lymphocytes, Hb, PLR and WBC of the severe OSAS patients was $14.38 \pm 3.80$ $\mathrm{mm} / \mathrm{hr}, \quad 1.72 \pm 1.47 \mathrm{mg} / \mathrm{L}, \quad 175.34 \pm 5.90 \mathrm{mg} / \mathrm{dl}, \quad 254.01 \pm 10.78 \times 10^{9} / \mathrm{L}, \quad 28.24 \pm 4.96 \%, \quad 14.06 \pm 1.14 \mathrm{~g} / \mathrm{dl}$, $141.60 \pm 19.83$ and $7720.83 \pm 27.44 \times 10^{6} / \mathrm{L}$ respectively. (Table. 2 ).

Significant differences were found between age $(\mathrm{p}=0.000)$, ESR $(\mathrm{p}=0.000)$, CRP $(\mathrm{p}=0.003)$, Cholesterol $(p=0.000)$, Platelets $(p=0.048), \mathrm{Hb}(p=0.000)$, PLR $(p=0.000)$ and white blood cells $(p=0.000)$, in groups. Association was found between gender $(p=0.000)$ and smoking status $(p=0.030)$ in groups. So, gender and smoking were the effect modifiers. (Table. 1-2).

Table. 1

Demographic Variables

\begin{tabular}{|c|c|c|c|c|c|}
\hline Variable & $\begin{array}{l}\text { Control group } \\
n=(63)\end{array}$ & $\begin{array}{|ll|}\text { Mild } & \text { OSAS } \\
\text { group } & \\
\mathbf{n}=(60) & \\
\end{array}$ & \begin{tabular}{l}
\multicolumn{2}{l}{ Moderate } \\
OSAS group \\
$n=(67)$
\end{tabular} & $\begin{array}{l}\text { Severe OSAS } \\
\text { group } n=(90)\end{array}$ & Test of Sig. \\
\hline Age & $\begin{array}{l}45.22 \pm 2.57 \\
\text { years }\end{array}$ & $\begin{array}{l}49.85 \pm 2.11 \\
\text { years }\end{array}$ & $\begin{array}{l}50.37 \pm 2.28 \\
\text { years }\end{array}$ & $\begin{array}{l}52.34 \pm 2.60 \\
\text { years }\end{array}$ & $\begin{array}{l}F=3.95 \\
p=0.000\end{array}$ \\
\hline BMI & $\begin{array}{l}23.90 \pm 2.66 \\
\mathrm{~kg} / \mathrm{m}^{2}\end{array}$ & $\begin{array}{l}24.03 \pm 2.74 \\
\mathrm{~kg} / \mathrm{m}^{2} \\
\end{array}$ & $\begin{array}{l}27.00 \pm 3.03 \\
\mathrm{~kg} / \mathrm{m}^{2}\end{array}$ & $\begin{array}{l}26.54 \pm 2.66 \\
\mathrm{~kg} / \mathrm{m}^{2}\end{array}$ & $\begin{array}{l}F=1.25 \\
p=0.175\end{array}$ \\
\hline Gender & $\begin{array}{l}\mathrm{M}=57.1 \%, \\
\mathrm{~F}=42.9 \%\end{array}$ & $\begin{array}{l}\mathrm{M}=76.7 \%, \\
\mathrm{~F}=23.3 \%\end{array}$ & $\begin{array}{l}\mathbf{M}=89.6 \%, \\
\mathrm{~F}=10.4 \%\end{array}$ & $\begin{array}{l}\mathbf{M}=82.2 \% \\
\mathrm{~F}=17.8 \%\end{array}$ & $\begin{array}{l}\chi^{2}=21.47, \\
p=0.000\end{array}$ \\
\hline $\begin{array}{l}\text { Smoking } \\
\text { Status }\end{array}$ & $\begin{array}{l}\text { Non- } \\
\text { smoker }=87.3 \% \text {, } \\
\text { Smoker }=12.7 \%\end{array}$ & $\begin{array}{l}\text { Non- } \\
\text { smoker }=90 \%, \\
\text { Smoker }=10 \% \\
\end{array}$ & $\begin{array}{l}\text { Non- } \\
\text { smoker }=74.6 \% \text {, } \\
\text { Smoker }=25.4 \%\end{array}$ & $\begin{array}{l}\text { Non- } \\
\text { smoker }=74.4 \%, \\
\text { Smoker }=25.6 \%\end{array}$ & $\begin{array}{l}\chi^{2}=\mathbf{8 . 9 5} \\
, p=0.030\end{array}$ \\
\hline
\end{tabular}


Table. 2

Hematological Parameters Association with Obstructive Sleep Apnea Syndrome.

\begin{tabular}{|l|l|l|l|l|l|}
\hline Variable & $\begin{array}{l}\text { Control group } \\
\mathbf{n}=(\mathbf{6 3})\end{array}$ & $\begin{array}{l}\text { Mild OSAS } \\
\text { group } \\
\mathbf{n}=(\mathbf{6 0})\end{array}$ & $\begin{array}{l}\text { Moderate } \\
\text { OSAS group } \\
\mathbf{n}=(\mathbf{6 7})\end{array}$ & $\begin{array}{l}\text { Severe OSAS } \\
\text { group n=(90) }\end{array}$ & Test of Sig. \\
\hline $\begin{array}{l}\text { ESR, } \\
\mathbf{m m} / \mathbf{h o u r}\end{array}$ & $8.01 \pm 2.27$ & $18.25 \pm 2.29$ & $17.71 \pm 9.27$ & $14.38 \pm 3.80$ & $\begin{array}{l}\mathbf{F}=\mathbf{5 . 2 1}, \\
\mathbf{p}=\mathbf{0 . 0 0 0}\end{array}$ \\
\hline CRP, mg/L & $0.63 \pm 0.35$ & $1.31 \pm 0.85$ & $0.78 \pm 0.33$ & $1.72 \pm 1.47$ & $\begin{array}{l}\mathbf{F}=\mathbf{1 . 9 2}, \\
\mathbf{p}=\mathbf{0 . 0 0 3}\end{array}$ \\
\hline $\begin{array}{l}\text { Cholesterol, } \\
\text { mg/dl }\end{array}$ & $170.21 \pm 11.88$ & $185.72 \pm 5.58$ & $190.42 \pm 11.21$ & $175.34 \pm 5.90$ & $\begin{array}{l}\mathbf{F}=\mathbf{3 . 4 9} \\
\mathbf{p}=\mathbf{0 . 0 0 0}\end{array}$ \\
\hline $\begin{array}{l}\text { Platelets, } \\
\mathbf{1 0} / \mathbf{L}\end{array}$ & $221.35 \pm 12.11$ & $225.23 \pm 5.88$ & $230.96 \pm 4.69$ & $254.01 \pm 10.78$ & $\begin{array}{l}\mathbf{F}=\mathbf{1 . 4 9} \\
\mathbf{p}=\mathbf{0 . 0 4 8}\end{array}$ \\
\hline $\begin{array}{l}\text { Lymphocytes, } \\
\mathbf{\%}\end{array}$ & $36.25 \pm 5.00$ & $35.20 \pm 2.66$ & $31.88 \pm 4.37$ & $28.24 \pm 4.96$ & $\begin{array}{l}\mathbf{F}=\mathbf{1 . 3 9}, \\
\mathbf{p}=\mathbf{0 . 0 8 5}\end{array}$ \\
\hline Hb, g/dl & $12.95 \pm 1.30$ & $15.26 \pm 2.14$ & $13.01 \pm 2.08$ & $14.06 \pm 1.14$ & $\begin{array}{l}\mathbf{F}=\mathbf{2 . 7 1 ,} \\
\mathbf{p}=\mathbf{0 . 0 0 0}\end{array}$ \\
\hline PLR & $98.80 \pm 7.69$ & $114.90 \pm 2.13$ & $121.63 \pm 5.53$ & $141.60 \pm 19.83$ & $\begin{array}{l}\mathbf{F}=\mathbf{2 . 5 9}, \\
\mathbf{p}=\mathbf{0 . 0 0 0}\end{array}$ \\
\hline WBC, 10 $/ \mathbf{L}$ & $6760.23 \pm 14.10$ & $7287.03 \pm 24.08$ & $7314.83 \pm 23.36$ & $7720.83 \pm 27.44$ & $\begin{array}{l}\mathbf{F}=\mathbf{4 . 8 1 ,} \\
\mathbf{p}=\mathbf{0 . 0 0 0}\end{array}$ \\
\hline
\end{tabular}

Discussion

Study was concluded with two main findings. One, that platelet lymphocyte ratio, an inflammatory marker, was significantly raised in obstructive sleep apnea syndrome patients. Second, there was significant correlation between platelet lymphocyte ratio and AHI $(\mathrm{p}<0.05)$. So study showed a significant association between obstructive sleep apnea syndrome severity (represented by AHI) and systemic inflammation (represented by PLR).

Previous studies had shown that there is association of elevated platelet counts with poor outcome of cardiovascular (CV) diseases. \{13-14\}. And also there is association of lower lymphocytes count with higher mortality and morbidity of cardiovascular diseases $\{14\}$. So combination of these two markers have emerged as potential inflammatory marker and outcome predictor in many malignant diseases and cardio vascular diseases $\{15-16\}$. It has been also reported that platelet lymphocyte ratio is predictor of long term and in hospital mortality in patients with STEMI and non-STEMI $\{17-18\}$.

Platelets can interact with many inflammatory cells like dendritic cell, neutrophils, T-lymphocytes, mononuclear phagocytes and can also interact with endothelial cells. The relation between these cells and platelets might initiate the inflammation. Previous studied reported that activated platelets could initiate inflammation by recruitment of white blood cells.

Obstructive sleep apnea syndrome is not simple disorder that occurs during sleep. Multiple studies had shown that obstructive sleep apnea syndrome patients have increased levels of inflammatory markers compared to matched controls and after using continuous positive airway pressure as treatment, significant decrease in these markers occur $\{19\}$.

Previous study also reported results that are equivocal to our study and these results show that there is significant association between platelet lymphocyte ratio and severity of obstructive sleep apnea syndrome $\{20\}$. In this study there was also significant correlation between higher age and body mass index with higher AHI index.

Another study also supports this investigation with results that increased systemic inflammation assessed by platelet lymphocyte ratio with severity of obstructive sleep apnea syndrome $\{21\}$. 
In past there were conflicting reports about association of upper airway obstruction and inflammatory markers $\{22-23\}$. Korkmaz M.et al. $\{22\}$ reported that severity of systemic inflammation cannot be predicted by other traditional markers like C-reactive protein and ESR.

Explanation to the relationship between inflammation and severity of obstructive sleep apnea syndrome is sleep deprivation and intermittent hypoxia. Many reports had shown that obstructive sleep apnea syndrome develop inflammatory response and high level of inflammatory mediators like coagulation factor, inter cellular adhesion molecules (ICAM) and CRP $\{24\}$.

Calculation of platelet lymphocyte ratio is very cheap and easy method as compared to other mediators like interleukins (IL-6, IL-1b) and TNF-alpha. Study results showed that inflammation in obstructive sleep apnea syndrome patients can be predicted by platelet lymphocyte ratio. So this inexpensive and easy procedure should be adopted by pulmonologists to assess the inflammation in patients of obstructive sleep apnea syndrome on first stage.

Limitation of the study was that sample size was very small relatively and other inflammatory markers like ESR and CRP were not compared with platelet lymphocyte ratio.

Conclusion:

Platelet lymphocyte ratio was significantly raised in patients with obstructive sleep apnea syndrome. There was significant correlation between platelet lymphocyte ratio and AHI $(\mathrm{p}<0.05)$. So study showed that there was significant association between obstructive sleep apnea syndrome severity (represented by AHI) and systemic inflammation (represented by PLR).

Recommendations:

New inflammatory markers are required to investigate the level of systemic inflammation in obstructive sleep apnea syndrome patients. Platelet lymphocyte ratio, an easy, quick and cheap measurable marker on routine $\mathrm{CBC}$ analysis, could be considered for assessing the inflammation in obstructive sleep apnea syndrome patients.

Conflict of interest

None.

Funding source

None.

References

1. Franklin KA, Lindberg E. Obstructive sleep apnea is a common disorder in the population-a review on the epidemiology of sleep apnea. Journal of Thoracic Disease. 2015 Aug;7(8):1311.

2. Thorpy M. International classification of sleep disorders. InSleep Disorders Medicine 2017 (pp. 475 484). Springer New York.

3. Young T, Peppard PE, Gottlieb DJ. Epidemiology of obstructive sleep apnea: a population health perspective. American Journal of Respiratory And Critical Care Medicine. 2002 May 1;165(9):1217-39.

4. Pampati S, Manchikanti L. What Is the Prevalence of Symptomatic Obstructive Sleep Apnea Syndrome in Chronic Spinal Pain Patients? An Assessment of the Correlation of OSAS with Chronic Opioid Therapy, Obesity, and Smoking. Pain Physician. 2016 May;19(4):E569-79.

5. Kerley CP, Hutchinson K, Bolger K, McGowan A, Faul J, Cormican L. Serum vitamin D is significantly inversely associated with disease severity in Caucasian adults with obstructive sleep apnea syndrome. Sleep. 2016 Feb 1;39(2):293-300.

6. McNicholas WT, Bonsignore MR, Management Committee of EU Cost Action B26. Sleep apnoea as an independent risk factor for cardiovascular disease: current evidence, basic mechanisms and research priorities. European Respiratory Journal. 2007 Jan 1;29(1):156-78.

7. Ryan S, Taylor CT, McNicholas WT. Systemic inflammation: a key factor in the pathogenesis of cardiovascular complications in obstructive sleep apnoea syndrome?. Thorax. 2009 Jul 1;64(7):631-6.

8. Thomsen M, Ingebrigtsen TS, Marott JL, Dahl M, Lange P, Vestbo J, et al. Inflammatory biomarkers and exacerbations in chronic obstructive pulmonary disease. Jama. 2013 Jun 12;309(22):2353-61. 
9. Sunbul M, Gerin F, Durmus E, Kivrak T, Sari I, Tigen K, Cincin A. Neutrophil to lymphocyte and platelet to lymphocyte ratio in patients with dipper versus non-dipper hypertension. Clinical and Experimental Hypertension. 2014 Jul 1;36(4):217-21.

10. Alexandrakis MG, Passam FH, Moschandrea IA, Christophoridou AV, Pappa CA, Coulocheri SA, Kyriakou DS. Levels of serum cytokines and acute phase proteins in patients with essential and cancerrelated thrombocytosis. American Journal of Clinical Oncology. 2003 Apr 1;26(2):135-40.

11. Koseoglu S, Ozcan KM, Ikinciogullari A, Cetin MA, Yildirim E, Dere H. Relationship Between Neutrophil to Lymphocyte Ratio, Platelet to Lymphocyte Ratio and Obstructive Sleep Apnea Syndrome. Advances in clinical and experimental medicine: Official Organ Wroclaw Medical University. 2014 Dec;24(4):623-7.

12. Berry RB, Brooks R, Gamaldo CE, Harding SM, Marcus CL, Vaughn BV. The AASM manual for the scoring of sleep and associated events. Rules, Terminology and Technical Specifications, Darien, Illinois, American Academy of Sleep Medicine. 2012.

13. Iijima R, Ndrepepa G, Mehilli J, Bruskina O, Schulz S, Schömig A, Kastrati A. Relationship between platelet count and 30-day clinical outcomes after percutaneous coronary interventions Pooled analysis of four ISAR trials. Thrombosis and Haemostasis. 2007;98(4):852-7.

14. Ommen SR, Gibbons RJ, Hodge DO, Thomson SP. Usefulness of the lymphocyte concentration as a prognostic marker in coronary artery disease. The American Journal of Cardiology. 1997 Mar 15;79(6):812-4.

15. Ying HQ, Deng QW, He BS, Pan YQ, Wang F, Sun HL, et al. The prognostic value of preoperative NLR, d-NLR, PLR and LMR for predicting clinical outcome in surgical colorectal cancer patients. Medical Oncology. 2014 Dec 1;31(12):305.

16. Kurtul A, Murat SN, Yarlioglues M, Duran M, Ergun G, Acikgoz SK, et al. Association of platelet-tolymphocyte ratio with severity and complexity of coronary artery disease in patients with acute coronary syndromes. The American Journal of Cardiology. 2014 Oct 1;114(7):972-8.

17. Azab B, Shah N, Akerman M, McGinn JT. Value of platelet/lymphocyte ratio as a predictor of all-cause mortality after non-ST-elevation myocardial infarction. Journal of Thrombosis and Thrombolysis. 2012 Oct 1;34(3):326-34.

18. Ugur M, Gul M, Bozbay M, Cicek G, Uyarel H, Koroglu B, et al. The relationship between platelet to lymphocyte ratio and the clinical outcomes in ST elevation myocardial infarction underwent primary coronary intervention. Blood Coagulation \& Fibrinolysis. 2014 Dec 1;25(8):806-11.

19. Pack AI, Gislason T. Obstructive sleep apnea and cardiovascular disease: a perspective and future directions. Progress in Cardiovascular Diseases. 2009 Apr 30;51(5):434-51.

20. Song YJ, Kwon JH, Kim JY, Kim BY, Im Cho K. The platelet-to-lymphocyte ratio reflects the severity of obstructive sleep apnea syndrome and concurrent hypertension. Clinical Hypertension. 2016 Jan 4;22(1):1.

21. Günbatar H, Ekin S, Sünnetçioğlu A, Arısoy A, Çilingir BM, Aşker S, et al. The relationship between neutrophil-to-lymphocyte ratio and platelet-to-lymphocyte ratio in patients with obstructive sleep apnea syndrome. Dicle Tip Dergisi. 2015;42(3).

22. Korkmaz M, Korkmaz H, Küçüker F, Ayyıldız SN, Çankaya S. Evaluation of the association of sleep apnea-related systemic inflammation with CRP, ESR, and neutrophil-to-lymphocyte ratio. Medical science monitor: International Medical Journal of Experimental and Clinical Research. 2015;21:477.

23. Medeiros CA, De Bruin VM, Andrade GM, Coutinho WM, de Castro-Silva C, De Bruin PF. Obstructive sleep apnea and biomarkers of inflammation in ischemic stroke. Acta Neurologica Scandinavica. 2012 Jul 1;126(1):17-22.

24. Yokoe T, Minoguchi K, Matsuo H, Oda N, Minoguchi H, Yoshino Get al. Elevated levels of C-reactive protein and interleukin- 6 in patients with obstructive sleep apnea syndrome are decreased by nasal continuous positive airway pressure. Circulation. 2003 Mar 4;107(8):1129-34. 